\title{
Forest Sector Sustainability Communication in Europe: a Systematic Literature Review on the Contents and Gaps
}

\author{
Katja Lähtinen ${ }^{1}$ - Anne Toppinen ${ }^{2} \cdot$ Hannele Suojanen $^{2} \cdot$ Tobias Stern $^{3}$ • \\ Lea Ranacher ${ }^{4}$. Michael Burnard ${ }^{5,6}$. Manja Kitek Kuzman ${ }^{7}$
}

Published online: 6 July 2017

(C) The Author(s) 2017. This article is an open access publication

\begin{abstract}
Purpose of Review Stakeholder communication plays an important role in enhancing the societal sustainability and business acceptability of the forest sector. The purpose of this study is to present the current state of forest sector communication research with its stakeholders at different hierarchical levels of sustainability (i.e., societal, sectorial, corporate, and product sustainability) in Europe.

Recent Findings A systematic literature review was implemented to acquire information on the research outcomes related to sustainability communication between the forest sector
\end{abstract}

This article is part of the Topical Collection on Forest Policy, Economics and Social Research

Electronic supplementary material The online version of this article (doi:10.1007/s40725-017-0063-2) contains supplementary material, which is available to authorized users.

Katja Lähtinen

katja.lahtinen@uva.fi

Anne Toppinen

anne.toppinen@ helsinki.fi

Hannele Suojanen

hannele.suojanen@helsinki.fi

Tobias Stern

tobias.stern@uni-graz.at

Lea Ranacher

lea.ranacher@boku.ac.at

Michael Burnard

michael.burnard@iam.upr.si and different stakeholders presented in international peerreviewed journals between 2005 and 2015. The examined literature emphasizes the role of stakeholder communication for forest sector sustainability and acceptability, but no specific information seems to exist on how to communicate and build the forest sector image in the eyes of different stakeholders.

Summary The gap in the research information indicates that there is a need for more theoretical and empirical work on communication and image-building processes by, e.g., recognizing the specific communication needs of different
Manja Kitek Kuzman

manja.kuzman@bf.uni-lj.si Consortium of Seinäjoki, Seinäjoki, Finland

2 Department of Forest Sciences, University of Helsinki, Helsinki, FI, Finland

3 Institute of System Sciences, Innovation and Sustainability Research (ISIS), Karl-Franzens-Universität Graz, Graz, Austria

4 Market Analysis and Innovation Research, Kompetenzzentrum Holz GmbH (Wood K plus), Vienna, Austria

5 Andrej Marušič Institute, University of Primorska, Koper, Slovenia

6 Abelium, d.o.o., Research and Development, Ljubljana, Slovenia

7 Biotechnical Faculty, University of Ljubljana, Ljubljana, Slovenia 
stakeholders via two-way and proactive information exchange. In the development process of forest sector communication and image building, more efforts on sending wellspecified messages for well-targeted audiences should be made.

Keywords Stakeholders · Information · Channels · Acceptability $\cdot$ Sustainable development $\cdot$ Societal well-being

\section{Introduction}

During the 2000s, increasing pressures to find balance in using forest resources to enhance economic, environmental, social, and cultural benefits have emerged at the local, national, and regional levels (e.g., $[1,2])$. For example, intensified requirements for decreasing the impacts of forest resource usage to the ecosystems and increased interest in the society towards recreational benefits acquired from the forests have driven the request for forest sector to be responsive to a broad scope of environmental and societal issues [3]. Simultaneously, the global emphasis on enhancing sustainable development via increased renewable resource utilization has simulated large-scale demand for forest resources for many end uses, such as energy production (e.g., $[4,5])$.

Related to the discourse of sustainable development, sustainability communication refers to deepening an understanding and awareness of the relationship between humans and their environment together with consideration of economic, environmental, social, and cultural values and norms for creating general acceptance in the eyes of different actors in the society [6]. The fundamental purpose of sustainability communication is to enhance developing methods of interactions in the society to support people moving towards sustainable behavior and lifestyles [7]. In Europe, the forest companies involved in product and service businesses composing the forest sector has a pivotal role in the development of a sustainable society, where economic (e.g., profitability of businesses), environmental (e.g., securing ecosystem services), social (e.g., rural employment), and cultural (e.g., forestrelated traditions) aspects of using natural resources are taken into account. The forest sector's actual and perceived contribution to these issues, however, is dependent on management of stakeholder communication to acquire information on different societal needs to develop methods to meet their value expectations and enhancing social license to operate (SLO) (e.g., $[8-10,11 \bullet])$.

At the present time, there is no comprehensive understanding of public perceptions or expectations related to forest sector sustainability. Instead, information on forest sector sustainability information or communication issues is grounded in a diverse set of information related to, e.g., specific forest industry products, sustainability issues, or stakeholder groups (e.g., [5, 12-14]). As a comparison, findings from North America (e.g., [15]) are similar indicating that holistic information on societal perceptions of sustainability in the forest sector is lacking also in that area. The absence of this comprehensive understanding and the forest sector's close relationship to both society and the environment (e.g., [16]) set the sector apart as an excellent platform for making a contribution to general sustainability research.

The purpose of this study is to identify potential gaps in the scientific research on public acceptability and perceptions of the European forest sector (i.e., firms involved in product and service businesses) by studying at different hierarchical levels of sustainability (i.e., societal, sectorial, corporate, and product sustainability) [17]. Hence, this study provides a general view on the communication of sustainability issues between the forest sector (i.e., companies involved in forest product and service businesses) and its diverse stakeholders comprising identification of the communicators, messages, communication channels, and the target audiences.

\section{Stakeholders in the Forest Sector}

According to stakeholder theory [18], stakeholders are groups of people who have an impact on an organization and/or are influenced by it. Primary stakeholders are those without whose continuing participation the company would not survive (i.e., shareholders, employees, customers, suppliers, and the government), while secondary stakeholders are groups of people without direct transactions with the company, but otherwise affected by it (e.g., communities, civil society organizations, competitors, and the media). For the forest sector, growing public awareness related to environmental and social issues has created a great need to build and secure the legitimacy of operations through transparent production and management processes and trustful stakeholder relationships (e.g., $[19 \bullet \cdot])$.

Stakeholder management involves three main tasks [20]: (1) identifying important audiences, topics important to them, and appropriate methods to communicate with them; (2) maintaining relationships with them; and (3) improving those relationships. Furthermore, stakeholder management can be either reactive or proactive. Reactive stakeholder management relies on lessons learned in previous engagements, identification of how strengths have been utilized, how weaknesses can be avoided or minimized, and then determining how to manage future engagements. In contrast, the proactive approach focuses on the future activities to produce new opportunities for affecting and implementing collaboration with any stakeholders, composed of ethical communication strategies and tactics for managing opportunities and threats with a forward-looking attitude. Integrated communication with stakeholders comprises both the aspects of general 
management of public relations and marketing enhanced by informal connections, social interaction, and open communication systems. The mechanics of integrated communication include, for example, special focus on content (i.e., messages, the image to be created), channels, strategic audience targeting, and information sharing [21].

The European forest sector's stakeholder system is composed of various stakeholder groups each of which may interact with different hierarchical levels of sustainability with high societal relevance (Fig. 1). The forest sector operates at the forefront of a rapidly changing global business environment, in which the importance of issues related to social change, sustainability, and justice is constantly increasing [22]. Correspondingly, understanding and managing the needs of various stakeholder groups and improving communication with them through targeted messages are increasingly difficult as attitudes and needs evolve [19••].

The role of governments is to ensure that the interests of all stakeholder groups are considered and to bring the most critical normative issues into the legislative process [23]. In addition, governments may also cooperate with non-governmental organizations (NGOs) [24] in voluntary systems intended to enhance sustainability such as creation of certification labels like Nordic Swan or EU ecolabel (e.g., [25, 26]), which provide information on the sustainability impacts of companies and products $[19 \bullet \cdot]$. In the changing business environment and increasing demand for environmentally and socially acceptable business practices, financiers have emerged as a stakeholder group requesting certification systems and stakeholder communication for managing their own business risks [27]. The role of employees as a stakeholder group for forest sector is multidimensional, since workers are not only members of local communities, but also potential source of business success due to their tacit knowledge and individual relationships with other stakeholder group members [19••]. Relationships with the forest owners are critical for the forest sector, which is dependent on the availability of raw material for all of its processes [9]. As a result of this dependency, the natural environment can be considered a factor that is both affected by and affects forest sector operations (e.g., [28]). Finally, decisions related to the use nature affect society as a whole, for example, by creating or eliminating recreation possibilities and by changes to the landscape (e.g., [2]), making the general public an important stakeholder group that affects general opinion on the acceptability of forest sector activities.

The different stakeholder groups may differ in their perception of and demand for sustainability communication. As sustainability can be assessed at different reference levels (societal, sectorial, corporate, product), it is likely that not all stakeholders are, or should be, addressed at all levels in the same way. Societal sustainability (e.g., [29]), for example, focuses on the social dimension and impacts whereas the sectorial level refers to particular industries or branches of them (e.g., $[30,31])$. The societal level is highly relevant for the forest sector as society is often affected by the forest sector, for example, by ecosystem services. The sectorial level is relevant when it comes to referring on value chain sustainability and comparisons with other sectors. By corporate-level assessments [32], which is the most common level of sustainability communication for companies, individual companies can be compared with each other by information received from corporate responsibility reporting, for example (e.g., [33, 34]). Finally, sustainability is also considered at the product level, which, in case of wood products, is often associated with certification [35].

\section{Forest Sector Communication}

According to Lasswell's model of communication [36] also adaptable to sustainability communication [7], communication is a linear process including five elements: a communicator, a message, a medium, an audience, and an effect. Based on this, the process of communication can be described by

Fig. 1 The system of the European forest sector (i.e., companies within the forest product and service businesses) and its stakeholders in relation to the hierarchical levels of sustainability (adapted from [17])

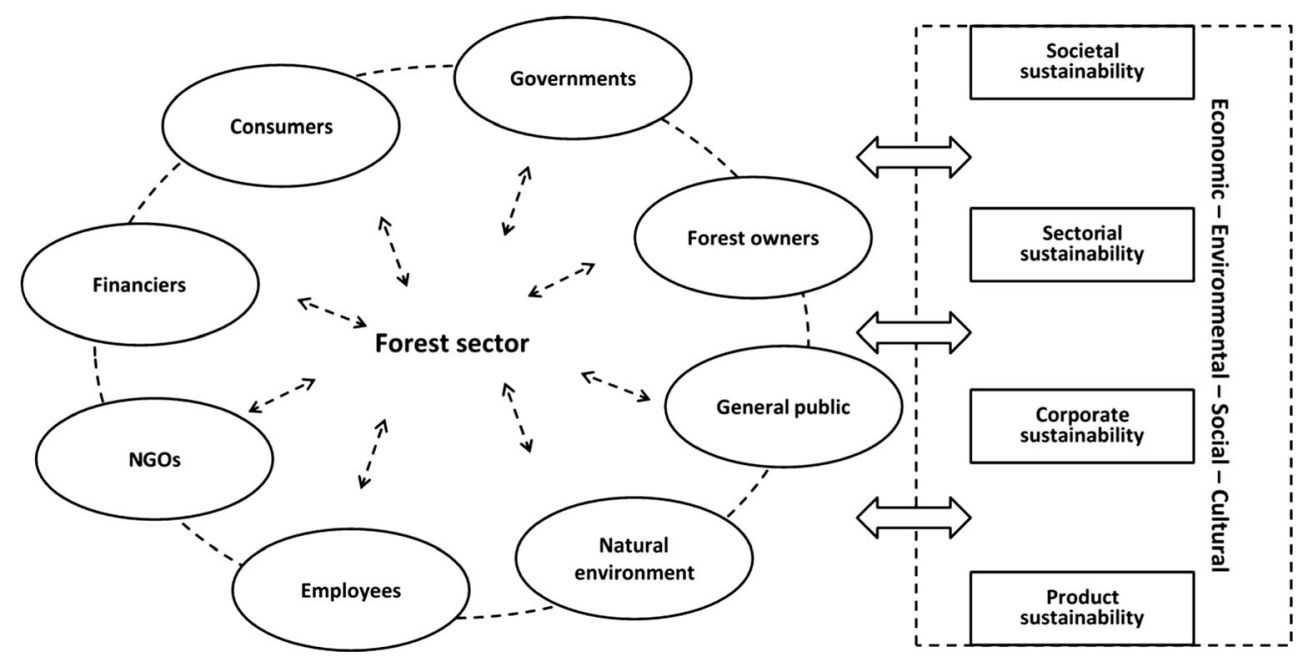


identifying the sender (communicator), the content of the message, the channel of communication (medium), the receiver of the message (audience), and the impact of communication (effect). If the flow of information goes only from the sender to the receiver, it can be considered as one-way communication based on information delivery (e.g., image-building campaigns and advertising). One-way communication has the inherent weakness of lacking the interaction between the sender and the receiver [37]. Consequently, the actual information needs of the receiver may not be met and this shortcoming may remain unknown, particularly in cases when the needs of different forest sector stakeholders are contradictory [38].

In contrast to one-way communication, two-way communication is composed of interaction between different elements of the communication process enabling a more proactive and engaging approach to seeking solutions to manage complex needs of different stakeholders (e.g., [39]). Furthermore, two-way communication can be divided into two categories, i.e., stakeholder response strategies with asymmetric characteristics and stakeholder involvement strategies with symmetry in communication between the communicator and stakeholder representing the audience $[37,40]$. Two-way symmetrical communication is characterized by a willingness to listen and respond to stakeholders, whereas in two-way asymmetrical communication, organizations listen to their stakeholders but do not make a corresponding alteration to their organizational processes [41]. Accordingly, successful communication between the communicator and the audience not only is not restricted to the dissemination of information, but also involves characteristics of making sense to messages, for example, providing information with a special value for the receivers [42].

With the rising emphasis on sustainability issues in the forest sector in the early 2000s (e.g., [19••]), communication practices and issues started to gain more attention within the industry and among researchers (e.g., $[40,43,44]$ ) as a measure to face the challenges of the sector. During this time, problems with communication activities and the image of the sector were recognized and acted as a driving force for bringing the needs for proactive and strategic communication to the forefront (e.g., [45]). In the course of time, the forest sector has focused mainly on one-way communication [43], by only sending communications outwards instead of engaging in bidirectional exchanges of information with their target audiences [37].
Due to its focus on one-way information delivery, forest sector communication has been criticized for lacking communication strategies based on meaningful interaction with the diverse stakeholders (e.g., [37, 43]). For example, according to the results of a large-scale survey implemented in Europe [24], the forest sector has lacked simple, coordinated, and effective messages that meet the needs of the various stakeholders. As a solution for the deficiencies in communication, utilizing a strong media presence and coordinated campaigns with clear messages explaining forest-related topics in understandable ways were presented [24].

The theoretical framework of this study is based on Lasswell's model of communication [36] as illustrated in Fig. 2. In this study, classifications of the differences between one-way and two-way communications are context-specific. For example, mediums that do not provide possibilities for interactions between the sender and receiver (e.g., newspaper articles, static websites, and advertisements) are one-way communication processes, while mediums providing possibilities for exchange of information (e.g., many web-based services, education) are two-way communication processes. In addition, following Janse [43], communication can be categorized into internal communication within the forest sector core (e.g., forest industries, employees, forest owners, authorities dealing with forestry issues, and science), external communication with clusters in connection with the forest sectors (e.g., NGOs, organizations operating in construction, information and communications technology and transportation), and external communication with society at large (e.g., consumers and general public).

\section{Material and Methods}

This study examined peer-reviewed research articles published or in the state of "in press" between January 2005 and October 2015 in international peer-reviewed scientific journals. Searches were carried out using the ScienceDirect database by using pre-determined search words for titles, abstracts, and keywords to concentrate on the themes directly relevant to the European forest sector in relation to perceived sustainability and acceptability expectations of different stakeholder groups. In addition, the expectations were scrutinized in regard to levels of societal, sectorial, corporate, and product

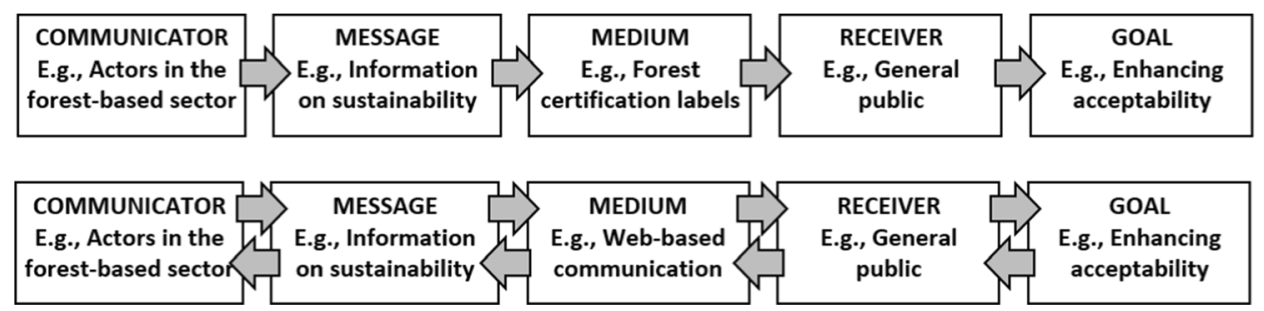

\section{One-way communication}

Symmetric \& asymmetric two-way communication

Fig. 2 Models of communication processes in the forest sector (adapted from [36, 37, 43]) 
sustainability. To focus directly on the state of stakeholder communication in the European forest sector, general sustainability studies without clear links to stakeholder sustainability information or communications were excluded from this systematic literature review.

Materials were gathered following established systematic literature review methodology (e.g., $[5,46])$ by employing ScienceDirect database searches. Prior to the systematic literature review, search terms were identified by using previous literature and the expert knowledge of the researchers involved in this study. The actual systematic literature review of this study comprised steps 1,2 , and 3. Step 1 comprised the database searches with pre-defined terms followed by step 2 , where all the materials found in step 1 were thoroughly checked. In order to avoid selection bias resulting from an overly strict selection procedure, even the abstracts with seemingly weak relevance to this study were selected for further review in step 3. In step 3, the whole contents of the articles selected in step 2 were studied to identify the initial set of articles for the material of this study.

As can be seen in Fig. 3, step 1 comprised seven rounds of database inquiries implemented by eight search terms to identify sectorial relevance combined with 18 thematic search terms leading to a total of 126 searches. A detailed description of the search words used in step 1 and the number of hits received in search rounds are illustrated in Fig. 3. During the selection process, the articles to review were reduced from 2305 hits received in ScienceDirect to 26 journal articles strictly relevant to this study.

As can be seen in Fig. 3, only 76 abstracts proceeded from step 1 to step 2 despite including abstracts with seemingly weak relevance to study for further consideration in step 3 .

\begin{tabular}{|c|c|c|c|c|c|c|}
\hline \multicolumn{7}{|c|}{$\begin{array}{r}\text { STEP } 1 \\
\text { Literature searches in Science Direct database with pre-defin } \\
\text { In total } 2305 \text { hits }\end{array}$} \\
\hline $\begin{array}{c}\text { Forest Sector } \\
\text { AND } \\
\text { Communication } \\
\text { Image } \\
\text { Stakeholders } \\
\text { Relationships } \\
\text { Responsibility } \\
\text { Trade-Offs } \\
\text { Risk Management } \\
\text { Technological Risk } \\
\text { Societal Risks } \\
\text { Consumers } \\
\text { Performance } \\
\text { Perceptions } \\
\text { Awareness } \\
\text { Attractiveness } \\
\text { Acceptance } \\
\text { Information } \\
\text { Sustainability } \\
\text { Society } \\
\mathbf{1 6 6} \text { hits } \\
\end{array}$ & $\begin{array}{c}\text { Forest Industry } \\
\text { AND } \\
\text { Communication } \\
\text { Image } \\
\text { Stakeholders } \\
\text { Relationships } \\
\text { Responsibility } \\
\text { Trade-Offs } \\
\text { Risk Management } \\
\text { Technological Risk } \\
\text { Societal Risks } \\
\text { Consumers } \\
\text { Performance } \\
\text { Perceptions } \\
\text { Awareness } \\
\text { Attractiveness } \\
\text { Acceptance } \\
\text { Information } \\
\text { Sustainability } \\
\text { Society } \\
\mathbf{1 1 9} \text { hits } \\
\end{array}$ & $\begin{array}{c}\text { Forestry } \\
\text { AND } \\
\text { Communication } \\
\text { Image } \\
\text { Stakeholders } \\
\text { Relationships } \\
\text { Responsibility } \\
\text { Trade-Offs } \\
\text { Risk Management } \\
\text { Technological Risk } \\
\text { Societal Risks } \\
\text { Consumers } \\
\text { Performance } \\
\text { Perceptions } \\
\text { Awareness } \\
\text { Attractiveness } \\
\text { Acceptance } \\
\text { Information } \\
\text { Sustainability } \\
\text { Society } \\
\text { 1016 hits } \\
\end{array}$ & $\begin{array}{c}\text { Forest Products } \\
\text { AND } \\
\text { Communication } \\
\text { Image } \\
\text { Stakeholders } \\
\text { Relationships } \\
\text { Responsibility } \\
\text { Trade-Offs } \\
\text { Risk Management } \\
\text { Technological Risk } \\
\text { Societal Risks } \\
\text { Consumers } \\
\text { Performance } \\
\text { Perceptions } \\
\text { Awareness } \\
\text { Attractiveness } \\
\text { Acceptance } \\
\text { Information } \\
\text { Sustainability } \\
\text { Society } \\
\mathbf{3 5 6} \text { hits } \\
\end{array}$ & $\begin{array}{c}\text { Wood Products } \\
\text { AND } \\
\text { Communication } \\
\text { Image } \\
\text { Stakeholders } \\
\text { Relationships } \\
\text { Responsibility } \\
\text { Trade-Offs } \\
\text { Risk Management } \\
\text { Technological Risk } \\
\text { Societal Risks } \\
\text { Consumers } \\
\text { Performance } \\
\text { Perceptions } \\
\text { Awareness } \\
\text { Attractiveness } \\
\text { Acceptance } \\
\text { Information } \\
\text { Sustainability } \\
\text { Society } \\
\mathbf{1 8 8} \text { hits } \\
\end{array}$ & $\begin{array}{c}\text { Paper Products } \\
\text { AND } \\
\text { Communication } \\
\text { Image } \\
\text { Stakeholders } \\
\text { Relationships } \\
\text { Responsibility } \\
\text { Trade-Offs } \\
\text { Risk Management } \\
\text { Technological Risk } \\
\text { Societal Risks } \\
\text { Consumers } \\
\text { Performance } \\
\text { Perceptions } \\
\text { Awareness } \\
\text { Attractiveness } \\
\text { Acceptance } \\
\text { Information } \\
\text { Sustainability } \\
\text { Society } \\
\mathbf{4 4} \text { hits } \\
\end{array}$ & $\begin{array}{c}\text { Furniture } \\
\text { AND } \\
\text { Communication } \\
\text { Image } \\
\text { Stakeholders } \\
\text { Relationships } \\
\text { Responsibility } \\
\text { Trade-Offs } \\
\text { Risk Management } \\
\text { Technological Risk } \\
\text { Societal Risks } \\
\text { Consumers } \\
\text { Performance } \\
\text { Perceptions } \\
\text { Awareness } \\
\text { Attractiveness } \\
\text { Acceptance } \\
\text { Information } \\
\text { Sustainability } \\
\text { Society } \\
\mathbf{4 1 6} \text { hits } \\
\end{array}$ \\
\hline \multicolumn{7}{|c|}{5} \\
\hline \multicolumn{7}{|c|}{$\begin{array}{l}\text { Scanning the contents of abstracts found by using the pre-defined search term combinations in STEP } 1 \\
\text { In total } 76 \text { abstracts selected for further review }\end{array}$} \\
\hline & The & content not reles & $\begin{array}{l}\text { Exclusion criteria } \\
\text { ant from the per }\end{array}$ & pective of the rev & iew & \\
\hline \multicolumn{7}{|c|}{ Examination of the contents of the literature selected in STEP 2} \\
\hline \multicolumn{7}{|c|}{ The content not relevant from the perspective of the review } \\
\hline \multicolumn{7}{|c|}{ INITIAL MATERIAL OF THE STUDY COMPRISING 26 INTERNATIONAL PEER-REVIEWED ARTICLES } \\
\hline
\end{tabular}

Fig. 3 Implementation of material gathering with a systematic literature review methodology 
This was caused by the fact that relatively little of research exists specifically related to forest sector information delivery and communication, although sustainability and acceptability issues have gained increasing attention in general societal discussions especially during the 2000s. Furthermore, scanning the titles of the 26 selected articles (Appendix) shows that, at a conceptual level, the terms "information" or "communication" have not been commonly employed in the context of forest sector stakeholder or sustainability studies.

\section{Results}

The results of this study are organized according to the four hierarchical levels of sustainability: societal (Table 1), sectorial (Table 2), corporate (Table 3), and product sustainability (Table 4). Overall, the systematic literature review revealed substantial differences in the quality and contents of stakeholder communication at different hierarchical levels of sustainability by different stakeholder groups. This review focused on the stakeholders identified in Fig. 1; however, no results related to financiers were found while designers, engineers, and scientists were identified as separate and important stakeholder groups.

In general, stakeholder communication in the forest sector is inconsistent: issues related to the different hierarchical levels of sustainability were not approached evenly with all stakeholders. Another important result is the fact that in most cases, there was no clear definition of the mediums (channels) employed to communicate sustainability-related information between stakeholders using either one-way or two-way communication. However, in the 26 articles reviewed in this study, it was possible to identify the communicator, the audience, and the sustainability content in most cases.

Table 1 provides a summary of results related to societal sustainability communication from seven articles examining multiple European countries. The communication relationships at the level of the societal sustainability have been between governments (communicator) and the general public (audience), forest owners (communicator) and governments (audience), the general public and stakeholders in general (audience), and the whole forest sector (communicator) and the general public (audience). According to the results, the content of communication has been related to governance topics (e.g., national- and EU-level forest policies) and the search for solutions to balance the various needs and expectations of different stakeholders related to forest management practices in rural and urban areas. Regarding the types of information exchange, both one-way (e.g., newsletters), two-way asymmetric (e.g., websites, contact and information offices, social surveys), and two-way symmetric (e.g., public workshops and interactive web-based tools) methods of communication have been discussed. Overall, Table 1 shows a considerable amount of examples given in a couple of studies on the potential of using two-way symmetric mediums in communicating on societal sustainability, although in general, their implementation in the forest sector information exchange seems to be scarce.

The results on sectorial sustainability are presented in Table 2 based on the content of five articles related to Finland, Germany, Romania, and UK. In comparison with communication on societal sustainability, the results in the literature show less variety in both communicators and audiences. Actually, the only identified communicators of sectorial sustainability are governmental bodies implementing information exchange towards forest sector actors (e.g., forest owners, employees, and NGOs). However, let it be mentioned that in the reviewed articles, no differentiation was made between different types of forest sector stakeholders acting as target audiences. Therefore, in Table 2, forest sector stakeholders are combined into one group representing the stakeholders of the sector in general.

Regarding sectorial sustainability, information exchange between governments (communicator), the forest sector (audience), and forest owners (audience) has been related to the implementation of different forest policy actions, programs, governmental objectives (e.g., producing wood for energy), and an effort to enhance the acceptability of these governmental actions with forest sector representatives. However, no clear definition of the appropriate mediums for implementing these communications effectively existed in the literature. As an exception to this, in the case of the construction sector (audience), governmental tools for enhancing acceptability were identified comprising various asymmetric and symmetric communication mediums from TV programs to education.

Corporate sustainability communication was covered in five articles, which detailed the circumstances in several countries (Table 3). According to the literature, communication of corporate sustainability has been from governments (communicator) towards the general public (audience) and forest owners (audience) and from the forest sector (communicator) towards the general public (audience) and NGOs (audience). The communicated content has been related to enhancing nature protection in general (government) or in a more focused way (forest sector) through corporate responsibility reporting and forest certification labels. In the area of corporate sustainability communication, most of the mediums have been composed of one-way information delivery tools (e.g., newspapers, magazines, certification labels), although two-way asymmetric ways of communication have been mentioned as well (e.g., information from forestry professionals).

In comparison with articles approaching societal, sectorial, and corporate sustainability, articles related to product sustainability (Table 4) identified mediums of communication more frequently. Altogether, six out of nine studies comprising findings related to the UK (and USA), Denmark, Finland, Greece, 
Table 1 Research results on sustainability communication in the forest sector at the hierarchical level of societal sustainability

Communicator Medium Audience Research findings Geographic area

Governments Not identified

Newsletters, websites, contact and information offices, public events, social surveys and interviews, public workshops, thinking days, youth work-play events, and education activities

Interactive web-based tools, online databases for e-learning
Forest owners Not identified

Forest sector Not identified
General public

General public

General public

Governments, general public, and other stakeholders in the society

Governments

(i.e., public authorities working with legislation)
Designing more legitimate forest policy requires wider perspective on the benefits of the forests (e.g., recreation), more flexible forest management practices, more attention to the justice of decision-making procedures, e.g., by equal treatment of all stakeholders [47].

Implementing successful communication processes among different stakeholders in urban forestry is challenging, since all participants should be able to connect each other's messages to their own frames of references. With potential conflicting interests between different stakeholders, their experiences, knowledge, and social settings affect communication [48].

Establishment and management of green infrastructure by urban forestry require involvement of complex and heterogeneous stakeholder groups. Stakeholders need better understanding of the importance of forming collaborative teams, optimizing financial resources, and having a common language to overcome the challenges posed by their diverse needs and backgrounds. An important approach for this is combining scientific knowledge dissemination with practical training to support easy access to the latest knowledge, e.g., via the internet, which remains an underutilized tool in the forest sector [49].

Communication strategies among forest owner associations should and could be improved by considering, e.g., objectives, messages, targets, and channels. Success would require benchmarking more experienced organizations, defining clear messages, utilizing a variety of communication, collaboration with other organizations (e.g., agriculture and wood construction), and using mass media and communication professionals [50]

More open and purposeful analysis of Finland stakeholder interests is needed when preparing legislation related to bioenergy production and pushing innovations linked to increased value of products [51].
Finland

Italy, Belgium, Finland, UK, Sweden, and Denmark

Europe and some areas outside Europe (not identified)
Czech Republic, Estonia, Finland, France, Germany, Sweden, Norway, Switzerland, Lithuania, Luxembourg, Slovenia, Spain, UK, Latvia, Hungary

Not identified 
Table 1 (continued)

\begin{tabular}{|c|c|c|c|c|}
\hline Communicator & Medium & Audience & Research findings & Geographic area \\
\hline & & $\begin{array}{l}\text { Governments } \\
\quad \text { (i.e., public } \\
\text { authorities } \\
\text { with an impact } \\
\text { on EU } \\
\text { policies) }\end{array}$ & $\begin{array}{l}\text { As forest-related questions have come } \\
\text { to the EU to stay, the important } \\
\text { question is not whether there will } \\
\text { be some kind of formal European } \\
\text { forest policy, but what form EU } \\
\text { forest policy will take. In this, both } \\
\text { the preferences and strategies of } \\
\text { stakeholders have a fundamental } \\
\text { role [52]. }\end{array}$ & \\
\hline & Public participation & General public & $\begin{array}{l}\text { Coordination and compromises } \\
\text { between heterogeneous groups of } \\
\text { stakeholders are needed in forest } \\
\text { management. In this, } \\
\text { communication between different } \\
\text { groups of stakeholders together } \\
\text { with their participation in } \\
\text { decision-making is crucial. } \\
\text { Communication between forestry } \\
\text { representatives and forest industries } \\
\text { is good. In addition, } \\
\text { communication also exists among } \\
\text { forestry representatives, forest } \\
\text { industries, and the nature } \\
\text { management sector, which is not } \\
\text { perceived positively among forest } \\
\text { owners and their organizations. In } \\
\text { managing diverse interests, } \\
\text { decision makers should try to } \\
\text { distribute power between different } \\
\text { stakeholders fairly instead of trying } \\
\text { to eliminate it [53]. }\end{array}$ & Norway \\
\hline
\end{tabular}

Germany, Switzerland, Spain, and Sweden contained information on the mediums employed to deliver messages between the governments and NGOS (communicators) and consumers (audience), as well as between the forest sector (communicator) and consumers (audience), the general public (audience), environmental technicians and engineers (audience), and architects (audience). However, related to the characteristics of the mediums employed, approaches for communicating with the audiences are related to one-way information dissemination like employing forest certification labels or advertisement, while two-way communication such as participatory processes to enhance knowledge was mentioned only once in the literature.

Table 5 is a summary of the roles that stakeholders in the forest sector take as communicators and audiences as well as the mediums of communication that they use (one-way, asymmetric two-way, and symmetric two-way communication). In general, it can be noted that in the literature, stakeholders were mentioned to have been involved in many types of communication activities both as communicators and audiences. Yet, as in some cases, the findings in Table 5 are grounded on findings of one study (e.g., symmetric two-way forest sector communication on product sustainability), they provide merely indications whether some types of communication seem to have even existed in the forest sector, instead of illustrating the magnitude of implementation of different models of communication processes among forest sector stakeholders at different levels of sustainability.

In general, the government is the only stakeholder group, which has been active as a communicator at all hierarchical levels of sustainability. In addition, excluding product sustainability, governmental bodies have also employed all types of mediums in their communication efforts. Along with the government, only the forest sector as a whole (societal and corporate sustainability), forest owners (societal sustainability), and NGOs (product sustainability) were considered as communicators attempting to affect the views of acceptability in the eyes of other forest sector stakeholders. In other words, there was no literature that indicated that consumers, financiers, employees, the natural environment, the general public, scientists, the construction sector, environmental technicians, designers, or architects were involved at all in disseminating forest sector information as communicators.

The stakeholders groups most frequently targeted by communicators were the general public (regarding societal, corporate, and product sustainability), NGOs (sectorial and product 
Table 2 Research results on sustainability communication in the forest sector at the hierarchical level of sectorial sustainability

\begin{tabular}{|c|c|c|c|c|}
\hline Communicator & Medium & Audience & Research findings & $\begin{array}{l}\text { Geographic } \\
\text { area }\end{array}$ \\
\hline \multirow[t]{5}{*}{ Governments } & Not identified & $\begin{array}{l}\text { Forest sector (e.g., forest owners, } \\
\text { administrative organizations, } \\
\text { employees, NGOs) }\end{array}$ & $\begin{array}{l}\text { In developing Regional Forest Programmes (RFP), } \\
\text { emphasis should be on motivating all different } \\
\text { stakeholder groups to involve in the process and to } \\
\text { increase the commitment of all important stakeholder } \\
\text { groups to RFPs and developing methods to reach } \\
\text { viewpoints of general audience more efficiently [54]. }\end{array}$ & Finland \\
\hline & Not identified & $\begin{array}{l}\text { Forest sector (e.g., state forestry } \\
\text { representatives, forest owners, } \\
\text { NGOs, scientists) }\end{array}$ & $\begin{array}{l}\text { Perceptions and attitudes toward participation in forest } \\
\text { policy differed notably among different stakeholder } \\
\text { groups. Private forest owners were the most skeptical, } \\
\text { while nature conservation groups favored most } \\
\text { increase in participation. In addition, no substantial } \\
\text { mutual policy learning among stakeholders or } \\
\text { improvements in the relationships between actors } \\
\text { representing production and conservation were } \\
\text { observed [55]. }\end{array}$ & Germany \\
\hline & Not identified & $\begin{array}{l}\text { Forest sector (e.g., forest owners, } \\
\text { local and county public } \\
\text { administration representatives) }\end{array}$ & $\begin{array}{l}\text { Lack of confidence exists between forest owners and } \\
\text { forest management structures (e.g., professional } \\
\text { foresters). To overcome this problem, landowners } \\
\text { could be trained in forestry to build communication } \\
\text { bridges between professional foresters and forest } \\
\text { owners [56]. }\end{array}$ & Romania \\
\hline & Not identified & Forest owners & $\begin{array}{l}\text { Attitudes of non-industrial private forest owners toward } \\
\text { energy wood production are positive, but increasing } \\
\text { the supply requires more information on, e.g., } \\
\text { production technologies and energy wood markets. In } \\
\text { addition, information needs seemed to be linked with } \\
\text { urban living far from the forest estate [57]. }\end{array}$ & Finland \\
\hline & $\begin{array}{l}\text { TV programs, green } \\
\text { building awards, } \\
\text { education, and training } \\
\text { programs }\end{array}$ & $\begin{array}{l}\text { Construction sector (i.e., experts } \\
\text { representing NGOs) }\end{array}$ & $\begin{array}{l}\text { UK government has played crucial role in promoting } \\
\text { wood construction. Experts with sound knowledge on } \\
\text { the wood as a construction material agree on its } \\
\text { superior environmental credentials, while end users } \\
\text { who may lack information and knowledge often show } \\
\text { strong prejudices against its use [58]. }\end{array}$ & UK \\
\hline
\end{tabular}

sustainability), and forest owners (sectorial and corporate sustainability). The stakeholder groups acting as audiences at only one hierarchical level of sustainability were governments (societal sustainability), consumers (product sustainability), employees (sectorial sustainability), the forest sector as a whole (sectorial sustainability), scientists (sectorial sustainability), the construction sector (sectorial sustainability), and environmental technicians, designers, or architects (product sustainability).

\section{Discussion}

The forest sector's actual and perceived contribution to enhancing sustainable development and societal well-being is dependent on success in communication to acquire information on needs of different stakeholders and enhancing SLO, for example (e.g., [8, 9]). For gaining "sustainable superiority" (e.g., [72, 73]), the forest sector must be both perceived as highly sustainable and be highly sustainable in their operations. Otherwise, there is a risk of being positioned in the society as "green washers" (high perceived, low actual sustainability) or "opportunity losers" (high actual, low perceived sustainability), which both are risks for gaining SLO.

The purpose of this study has been to present an overview on the communicators, messages, communication channels, and the target audiences at different hierarchical levels of sustainability within the system of the European forest sector during the 2000s. From the perspective of the forest sector, focal issues in sustainability communication are connected to the enhancement of the social license to operate (SLO) from the perspective of different stakeholders and their value expectations. The material of the study was composed of studies related to the scope of the study published in January 2005October 2015 in international peer-reviewed journals. As a research methodology for gathering the relevant literature, a systematic literature review approach has been employed.

According to the results of the analysis, a relatively large body of research information related to sustainability and acceptability exists. In the existing studies, main findings are 
Table 3 Research results on sustainability communication in the forest sector at the hierarchical level of corporate sustainability

$\begin{array}{lll}\text { Communicator Medium Audience Outcome of research } & \text { Geographic } \\ \text { area }\end{array}$

Governments EU policy instruments, sustainability standards, General and certification schemes public

Information from forestry professionals, neighboring forest owners, local newspapers, forestry magazines

Forest

owne-

rs

(1)

Forest sector Corporate responsibility reporting

Forest certification labels

Not identified

NGOs
Forest industry companies could potentially benefit from Finland

proactive, strategic, and a self-organized approach to sustainability management by exceeding the norm-level regarding, e.g., energy and material efficiency, recycling, and waste prevention/utilization. At the moment, they are not receiving sufficient focus from corporate management. In addition, forest industry companies should have more guidance on sustainability management issues via EU-level or national regulatory frameworks [59].

Delivering the message of voluntary protection has been Finland effective, especially via newspaper articles and in the context of preparing forest management plan together with Forestry Centre officials. The message of voluntary protection has gone through well, because in the eyes of forest owners, they represent "forestry people." In contrast, for some forest owners, officials in the Centre of Economic Development, Transport and Environment (ELY) represent "nature protection people," against whom they are prejudiced. However, the ones who have been in contact with ELY officials were highly satisfied with the collaboration afterwards [60].

General Forest sector businesses are obligated to responsibly and Global

public beneficially towards society while achieving a sustainable level of profitability. Along with the growth of ethical markets, companies could renew their businesses via corporate responsibility by making radical changes in fundamental values, policy principles, and operational procedures by organizational learning [16].

General Based on their webpages, companies operating in forestry Czech public and logging are very seldom involved in certification Republic (about one out of ten companies) or other forms of non-governmental actions (e.g., supporting youth hobbies). Regarding certification, most companies implementing corporate responsibility have PEFC certification [61].

Non-governmental engagement forms can be categorized Finland, into three general strategies: sponsorship, dialogue, and Brazil, partnerships. Among forest industries, understanding Poland, global pressures and opportunities in relation to Russia forming partnerships, voluntary governance (e.g., forest certification), stakeholder dialogue, and philanthropy is necessary [62]. related to communicators, audiences, and sustainability themes considered as important for different stakeholders. Thus, the existing research findings are general in nature and there seems to be a lack of coherent and profound knowledge on specific sustainability information needs of different stakeholders in Europe as well as appropriate and efficient communication channels regarding different levels of sustainability (i.e., societal, sectorial, corporate, product). While governments, as communicators, seem to employ both one-way and two-way communication channels quite broadly especially in the context of societal, sectorial, and product sustainability, all other actors (e.g., forest sector as a whole) seem to lack genuine information exchange with their various stakeholders regarding, for example, sectorial sustainability. As a general finding, it can be said that forest sector communication has remained to be dominated by reactive methods, while proactive approaches have been continued to be underutilized, as they were in the early 2000 s (e.g., [43]).

If forest sector organizations are to enhance their SLO among different stakeholders in the society, broad-scope and profound communication strategies in relation to different stakeholder needs at different hierarchical levels of 
Table 4 Research results on sustainability communication in the forest sector at the hierarchical level of product sustainability

\begin{tabular}{|c|c|c|}
\hline Communicator Medium & Audience & Outcome of research \\
\hline
\end{tabular}

Governments
and NGOs
and NGOs

Nordic Swan ecolabel

Consumers

Forest sector Not identified

Consumers

Effective advertisement, attractive packaging, and labeling

Not identified

Consumers

Marketing efforts, participatory processes to enhance knowledge

Product information

Consumers

Not identified

Promotion of wooden multi-storey construction with examples

Architects
Disclosing the origin of wood products has a significant effect UK and on consumer preferences. In the case of products originating USA from temperate forests, there is a positive impact related to information on raw material source. In contrast, the impact is negative when disclosing information on raw material acquirement from tropical forests. In general, attitudes among UK wood product consumers are stronger towards the need of environmental certification in comparison with US respondents [63].

To substantively expand the market for ecolabeled toilet paper Denmark products and paper towels among and beyond environmentally conscious consumers, products must be more readily available (e.g., widely available for purchasing) and present attractive bargains (e.g., sales) for consumers. In addition, governments can support ecolabeling programs to provide clear, consistent, and trusted information on the environmental characteristics of products [64].

Perceived quality of a product is composed of tangible (i.e., Finland technical quality, aesthetics, and design) and intangible (i.e., quality of suppliers and sales persons, and service and information as well as environmental friendliness, and domestic origin) [65] purchase. Communication about forest certification labels material from engineering aspects (i.e., fire safety, sound insulation, acoustics, stability, and durability), but the overall attitude towards using wood is positive related to its perceived environmental benefits [71].
General public

Positive attitudes seem to exist towards the future market potential for raw material originating from transgenic plantations. Consumers can be categorized into three types according to their preferences: those who would buy transgenic wood products, but would want them to be labeled as transgenic; those who are influenced mainly by the quality of wood products, its characteristics, and brand; and those who are not influenced in any way by the transgenic raw material origin of the wood products [66].

Information on origin (i.e., country), environmental impacts (i.e., sustainability of the raw material, carbon footprint, recycling), and material (e.g., type of wood, material composition, additives, and comments of the producers) should be widely available to young consumers. In addition, marketers should be able to disseminate the information to consumers [67].

Along with ecological issues, social views on forest management (e.g., aesthetics and leisure activities) in relation to the general public and forest visitors should be taken into account in creating certification labels. Among consumers, knowledge on forest certification labels is superficial although for having effect in the markets, consumers should recognize the labels during the time of should not focus only on ecologically or socially aware consumers, but also on the ones with economic orientation [68].

Providing consumers with product information with traceability information system could allow satisfying their needs for wood product information related to seeking for eco-friendly products at reasonable costs. To support this, consumers should be informed and instructed about the new service possibilities [69].

Environmental Analytical methodologies to assess environmental impacts of $\begin{array}{ll}\text { designers } & \text { Wooden furniture (i.e., Life Cycle Analysis and Design }\end{array}$ among environmental technicians and designers. In addition, they can be employed in further environmental analysis to improve environmental performance and sustainability of the furniture sector [70].

Wood is considered the least suitable construction frame

Germany

Switzerland

Germany

Spain

Sweden
Greece 
Table 5 Communicators and audiences at different hierarchical levels of sustainability by different types of communication within the system of the European forest sector

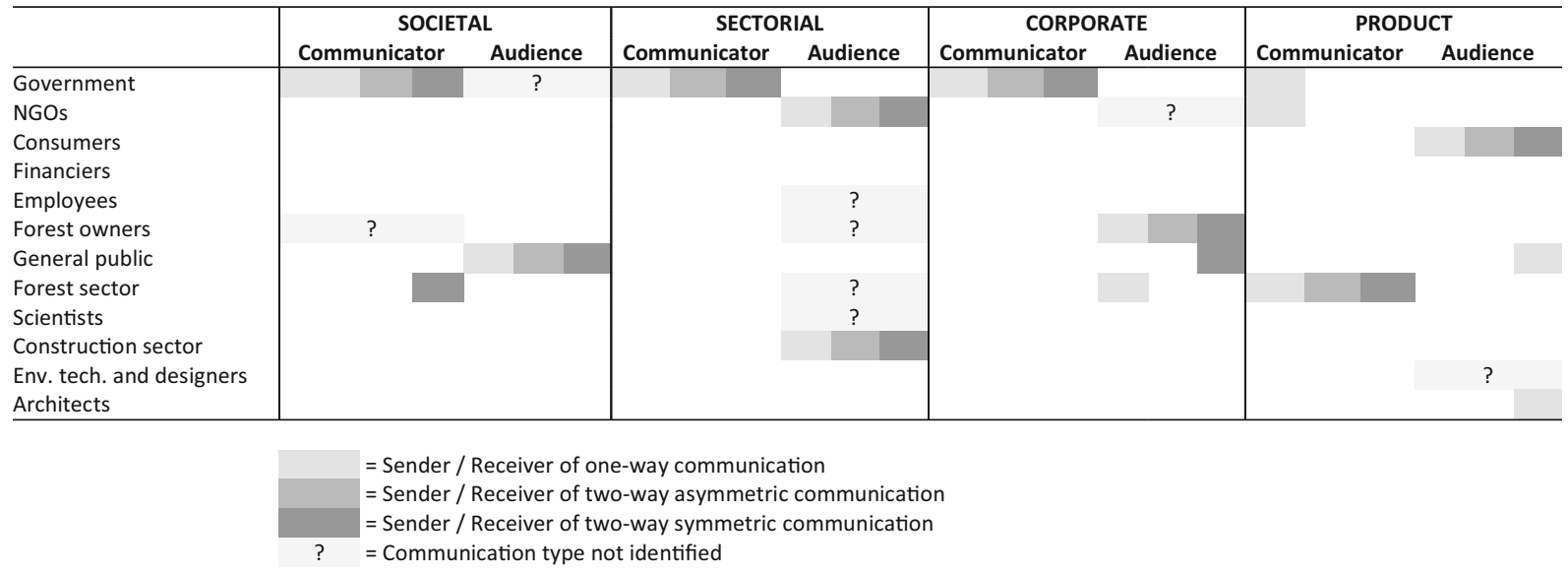

sustainability need to be developed. For example, for the forest sector as a whole, employing different models of communication (i.e., one-way, asymmetric, and symmetric communication) merely on product sustainability is not sufficient for enhancing acceptability of operations and competitiveness in the markets. In addition, although forest policy issues are not a focal point in the everyday life of the general public, governmental bodies are relatively active communicators on sustainability and general policy issues towards the general public. As such, it is good that governmental bodies are active in their communication, but should be asked whether information on societal issues (e.g., positive impacts caused by the forest sector in the form of climate change mitigation or new innovative product possibilities) would be more needed among the general public and closer to the decisions that consumers are making, for example, when purchasing forest products.

The lack of knowledge on stakeholder information needs and appropriate communication channels may be a consequence of deficiencies in stakeholder management. If stakeholder relationships were considered as a strategic asset for the organizations, well-targeted two-way symmetric interaction with the ones affecting and being affected by organizations' operations would probably be integrated into communication plans. Instead, as a result of gaps on stakeholder management, different actors in the forest sector seem to be very much focused on one-way communication without well-targeted messages or heterogeneous and purposeful employment of different communication channels.

To make a change in the forest sector communication, organizations should acknowledge the varying information needs of different audiences in order to effectively reach them. Regarding corporate sustainability communication, it has been stated that the value of providing information on those issues is limited as long as communication is not specifically targeted to relevant stakeholders [74]. In addition, proactive communication of future activities will be one way to produce new opportunities for meaningful collaboration with stakeholders that employ ethical communication strategies and tactics for managing opportunities and threats with a forward-looking attitude.

Regarding the reliability and validity of the results, some limitations associated with systematic literature reviews should be considered when weighing the outcome of this study. Most importantly, the lack of existing scientific publications on certain aspects of sustainability communication does not necessarily imply that these types of communication do not exist. For a variety of reasons, certain aspects of communication may not have been subject to research or the results may not have been published as journal papers. Furthermore, because of the significant time delay commonly associated with the scientific publication process, these study results should not be considered to fully cover all research performed during the target period. Additionally, only one database (ScienceDirect) was searched and therefore certain journals may be missing from the analysis. However, given that the analysis consisted of 26 papers in a narrow scope published during the last 10 years, this review can reasonably be considered to comprehensively cover the topic. Correspondingly, the latest developments in related areas, such as sustainability communications related to the bioeconomy, are not necessarily covered in detail.

\section{Conclusions}

The results of the study indicate a need to pay more theoretical and empirical attention to communication and image-building processes, for example, by recognizing the specific communication needs of different stakeholders via two-way and proactive information exchange. In addition to sending truthful messages, it is important to send messages that support stakeholders to perceive the societal benefits of the forest sector 
operations from different societal, sectorial, corporate, and product sustainability perspectives.

Tailoring forest sector communication and image building by sending well-specified messages for well-defined audiences is another critical aspect for improving forest sector communication. This issue should be addressed by future research projects as well as by practical communication activities in the sector. The analytical framework applied in this study could be used to study other sectors (agriculture, construction, chemical industries) as well in order to assess the sectorial differences in communication at different hierarchical sustainability levels when addressing different stakeholders.

Acknowledgements Financial support from ERANET WoodWisdom Net W3B partners and financiers is gratefully acknowledged. Work of authors in Slovenia was supported by the Ministry of education, science and sport.

\section{Compliance with Ethical Standards}

Conflict of Interest Lähtinen, Toppinen, Suojanen, Stern, Ranacher, Burnard and Kitek Kuzman declares no conflicts of interests.

Human and Animal Rights and Informed Consent This article does not contain any studies with human or animal subjects performed by any of the authors.

Open Access This article is distributed under the terms of the Creative Commons Attribution 4.0 International License (http:// creativecommons.org/licenses/by/4.0/), which permits unrestricted use, distribution, and reproduction in any medium, provided you give appropriate credit to the original author(s) and the source, provide a link to the Creative Commons license, and indicate if changes were made.

\section{References}

Papers of particular interest, published recently, have been highlighted as:

- Of importance

• Of major importance

1. Dargush P, Maraseni TN, Schmidt P. A review of research on forestrelated environmental markets (including certification schemes, bioenergy, carbon markets and other ecosystem services). CAB Rev Perspect Agric Vet Sci Nutr Nat Resour. 2010;5:1-12.

2. Lähtinen K, Myllyviita T. Cultural sustainability in reference to the Global Reporting Initiative (GRI) guidelines - case forest bioenergy production. J Cult Herit Manag Sustain Dev. 2015;5(3):290-318. doi:10.1108/JCHMSD-06-2013-0025.

3. Cohen D, Mathey A-H, Biggs J, Boyland M. Corporate social responsibility in the forest sector. In: Hansen E, Panwar R, Vlosky R, editors. The global forest sector - changes, practices, and prospects. CRC Press. Taylor \& Francis Group; 2014.

4. Jonsson R. How to cope with changing demand conditions - the Swedish forest sector as a case study: an analysis of major drivers of change in the use of wood resources. Can J For Res. 2013;43:40518 .
5. Lähtinen K, Myllyviita T, Leskinen P, Pitkänen S. A systematic literature review on indicators to assess local sustainability of forest energy production. Renew Sustain Energy Rev. 2014;40:1202-16. doi:10.1016/j.rser.2014.07.060.

6. Godemann J, Michelsen G. Sustainability communication - an introduction. In: Godemann J, Michelsen G, editors. Sustainability communication - interdisciplinary perspectives and theoretical foundations. 2011.

7. Kruse L. Psychological aspects of sustainability communication. In: Godemann J, Michelsen G, editors. Sustainability communication-interdisciplinary perspectives and theoretical foundations. Springer; 2011.

8. Korhonen E, Toppinen A, Lähtinen K, Ranacher L, Werner A, Stern T, et al. Communicating forest sector sustainability: results from four European countries. For Prod J. 2016;66(5-6):362-70. doi:10.13073/FPJ-D-15-00046.

9. Lähtinen K, Toppinen A, Mikkilä M, Toivio M, Suur-Uski O. Corporate responsibility reporting in promoting social license to operate in the forestry and sawmilling industries. Forestry. 2016;89(5):525-41.

10. Arminen H, Tuppura A, Toppinen A, Kozak R. Corporate responsibility development paths in the US forest sector. Forestry. 2016;89(5):500-11. doi:10.1093/forestry/cpv050.

11. Ranacher L, Lähtinen K, Toppinen A, Järvinen E. Perceptions of the general public on forest sector responsibility: a survey related to ecosystem services and forest sector business impacts in four European countries. Forest Policy Econ. 2017;78:180-9. doi:10. 1016/j.forpol.2017.01.016. The article approaches in a novel way from the perspective of establishment and management of European urban green infrastructures the possibilities to enhance efficient knowledge exchange between different stakeholders groups. Abreast with the viewpoints of communication, also the willingness and potential for future collaboration with other stakeholder groups are being discussed.

12. Amberla T, Wang L, Juslin H, Panwar R, Hansen E, Anderson R Students' perceptions of forest industries business ethics - a comparative analysis of Finland and the USA. Electron J Bus Ethics Org Stud. 2010;15(1):44-54.

13. Toivonen R, Toppinen A, Valkeapää A, Rämö A Consumer perceptions on environmental and social responsibility of wood products suppliers in the Finnish markets. In Toppinen A, Karppinen H, Kleemola K, editors. Proceedings of Biennial Meeting of the Scandinavian Society of Forest Economics, May 23-26, 2012, Finland. Scand Forest Econ 44; 2012.

14. Toppinen A, Toivonen R, Valkeapää A, Rämö A. Consumer perceptions on environmental and social responsibility of wood products in the Finnish markets. Scand J Forest Res. 2013;28(8):77583. doi:10.1080/02827581.2013.824021.

15. Panwar R, Hansen E, Kozak R. Evaluating social and environmental issues by integrating the legitimacy gap with expectational gaps: an empirical assessment of the forest industry. Bus Soc. 2012;53(5): 853-75.

16. Li N, Toppinen A. Corporate social responsibility and sustainable competitive advantage in the forest industry: complementary or conflicting goals? Forest Policy Econ. 2011;13:113-23. doi:10. 1016/j.forpol.2010.06.002.

17. Draper S. Corporate responsibility and competitiveness at the meso level - key models for delivering sector-level corporate responsibility. Corp Gov. 2006;6(4):409-19. doi:10.1108/ 14720700610689522.

18. Freeman R. Strategic management: a stakeholder approach. Marshfield: Pitman; 1984.

19.•• Toppinen A, Lähtinen K, Holopainen J. On corporate responsibility. In Panwar R, Kozak R, Hansen E, editors. Forests, business and sustainability. Earthscan; 2016. Chapter presents a new way to 
approach measurement systems as communication tools to enhance forest sector acceptability and sustainable value creation in relation to diverse stakeholder needs. As a new contribution, the linkages between sustainability assessment systems, their contents and management systems for long-term stakeholder engagement in the forest sector are being introduced.

20. Smudde PM, Courtright JL. A holistic approach to stakeholder management: a rhetorical foundation. Public Relat Rev. 2011;37: 137-44. doi:10.1016/j.pubrev.2011.01.008.

21. Smith BG. Communication integration: an analysis of context and conditions. Public Relat Rev. 2012;38:600-8. doi:10.1016/j.pubrev. 2012.06.003.

22. Lindahl KB, Westholm E. Future forests: perceptions and strategies of key actors. Scand J Forest Res. 2012;2:154-63. doi:10.1080/ 02827581.2011 .635073

23. Donaldson T, Preston LE. The stakeholder theory of the corporation - concepts, evidence, and implications'. Acad Manag Rev. 1995;20(1):65-91.

24. Rametsteiner E, Eichler L, Berg J. Shaping forest communication in the European Union: public perceptions of forest and forestry. Final Report. ECORYS; 2009.

25. Lehtoranta S, Nissinen A, Mattila T, Melanen M. Industrial symbiosis and the policy instruments of sustainable consumption and production. J Clean Prod. 2011;19(16):1865-75. doi:10.1016/j. jclepro.2011.04.002.

26. Räty T, Toppinen A, Roos A, Riala M, Nyrud AQ. Environmental policy in the Nordic wood product industry: insight into firms' strategies and communication. Bus Strateg Environ. 2016;25:10 27.

27. Nikolakis W, Cohen DH, Nelson HW. What matters for socially responsible investment (SRI) in the natural resources sectors? SRI mutual funds and forestry in North America. J Sustain Finance Invest. 2012;2(2):136-51.

28. Matthies B, D'Amato D, Berghäll S, Ekholm T, Hoen HF, Holopainen JM, et al. An ecosystem-service dominant logic?: integrating the ecosystem service and service-dominant logic approaches. J Clean Prod. 2016;124:51-64. doi:10.1016/j.jclepro. 2016.02.109.

29. Dempsey N, Bramley G, Power S, Brown C. The social dimension of sustainable development: defining urban social sustainability. Sustain Dev. 2011;19:289-300. doi:10.1002/sd.417.

30. Labuschagne C, Brent AC, van Erck RPG. Assessing the sustainability performances of industries. J Clean Prod. 2005;13(4):37385. doi:10.1016/j.jclepro.2003.10.007.

31. Azapagic A, Perdan S. Indicators of sustainable development for industry: a general framework. Process Saf Environ Prot. 2000;78(4):243-61. doi:10.1205/095758200530763.

32. Krajnc A, Glavič P. How to compare companies on relevant dimensions of sustainability. Ecol Econ. 2005;55(4):551-63. doi:10.1016/ j.ecolecon.2004.12.011.

33. Dyllick T, Hockerts K. Beyond the business case for corporate sustainability. Bus Strateg. 2002;11(2):130-141. http://www.scopus. com/inward/record.url?eid=2-s2.0-0036206314\&partnerID= 40\&md5=cfee0eb7697cc36298580cbff95fb375. doi:10.1002/bse. 323.

34. Linnenluecke MK, Griffiths A. Corporate sustainability and organizational culture. J World Bus. 2010;45(4):357-66. doi:10.1016/j. jwb.2009.08.006.

35. Cai Z, Aguilar FX. Meta-analysis of consumer's willingness-to pay premiums for certified wood products. J For Econ. 2013;19:15-31. doi:10.1016/j.jfe.2012.06.007.

36. Lasswell $\mathrm{H}$. The structure and function of communication in society. In: Bryson L, editor. The communication of ideas. New York: Institute for Religious and Social Studies; 1948.

37. Morsing M, Schultz M. Corporate social responsibility communication: stakeholder information, response and involvement strategies. Bus Ethics. 2006;15(4):323-38. doi:10.1111/j.14678608.2006.00460.x.

38. Rientjes S. Communicating nature conservation: a manual on using communication in support of nature conservation policy and action. Tilburg: European Centre for Nature Conservation; 2000. http:/ www.ecnc.org/uploads/2012/11/2000-Communicating-natureconservation-compressed.pdf

39. Crane A, Livesey S. Are you talking to me? Stakeholder communication and the risks and rewards of dialogue. In: Andriof $\mathrm{J}$, Waddock J, Rahman S, Husted B, editors. Unfolding stakeholder thinking: relationships, communication, reporting and performance. Sheffield: Greenleaf; 2003.

40. Janse G. Characteristics and challenges of forest sector communication in the EU. Silva Fenn. 2007a;41(4):731-53.

41. Roper J. Symmetrical communication: excellent public relations or a strategy for hegemony? J Public Relat Res. 2005;17(1):69-86. doi:10.1207/s1532754xjprr1701 6 .

42. Schoeneborn D, Tittin H. Transcending transmission. Towards a constitutive perspective on CSR communication. Corp Commun Int J. 2013;18(2):193-211. doi:10.1108/13563281311319481.

43. Janse G. European Co-operation and networking in forest communication. European Forest Institute. EFI Technical Report 20; 2005.

44. Janse G. Communication in forest policy decision-making in Europe: a study on communication processes between policy, science and the public. Disserationes forestales 48. University of Joensuu, Faculty of Forest Sciences; 2007b. Doctoral dissertation. 78 p. + appendices.

45. Hellström E. Strengthening European networking and co-operation in forest sector communication. In: Hellström E, editor. Proceedings of the Forest Academy Finland Forums 1-4. Helsinki: Forest Academy Finland; 2004.

46. Zhang Y, Toppinen A, Uusivuori J. Internationalization of the forest products industry: a synthesis of literature and implications for future research. Forest Policy Econ. 2014;38:8-16. doi:10.1016/j. forpol.2013.06.017.

47. Valkeapää T, Karppinen H. Citizens' view of legitimacy in the context of Finnish forest policy. Forest Policy Econ. 2013;28:529. doi:10.1016/j.forpol.2013.01.004.

48. Janse G, Konijnendijk CC. Communication between science, policy and citizens in public participation in urban forestry - experiments from the Neighbourwoods project. Urban For Urban Green. 2007;6:23-40. doi:10.1016/j.ufug.2006.09.005.

49. Ugolini F, Massetti L, Sanesi G, Pearlmutter D. Knowledge transfer between stakeholders in the field of urban forestry and green infrastructure: results of a European survey. Land Use Policy. 2015:36581. doi:10.1016/j.landusepol.2015.08.019.

50. Fabra-Crespo M, Rojas-Briales E. Comparative analysis on the communication strategies of the forest owners' associations in Europe. Forest Policy Econ. 2005;50:20-30. doi:10.1016/j.forpol. 2014.06.004.

51. Huttunen S. Stakeholder frames in the making of forest bioenergy legislation in Finland. Geoforum. 2014;53:63-73. doi:10.1016/j. geoforum.2014.02.006.

52. Bjärstig T. The Swedish forest sector's approach to a formalized forest policy within the EU. Forest Policy Eco. 2013;26:131-7. doi: 10.1016/j.forpol.2012.08.005.

53. Aasetre J. Perceptions of communication in Norwegian forest management. Forest Policy Econ. 2006;8:81-92. doi:10.1016/j.forpol. 2004.06.001.

54. Kangas A, Saarinen N, Saarikoski H, Leskinen LA, Hujala, Tikkanen J. Stakeholder perspectives about proper participation for regional Forest Programmes in Finland. Forest Policy Econ. 2010;12(3):213-22. doi:10.1016/j.forpol.2009.10.006.

55. Maier C, Lindner T, Winkel G. Stakeholders' perceptions of participation in forest policy: a case study from Baden-Wüttenberg. Land 
Use Policy. 2014;39:166-76. doi:10.1016/j.landusepol.2014.02. 018.

56. Dragoi M, Popa B, Blujeda V. Improving communication among stakeholders through ex-post transactional analysis - case study on Romanian forestry. Forest Policy Econ. 2011;131:16-23. doi:10. 1016/j.forpol.2010.08.007.

57. Rämö AK, Järvinen E, Latvala T, Toivonen R, Silvennoinen H. Interest in energy wood and energy crop production among Finnish non-industrial private forest owners. Biomass Bioenergy. 2009;33(9):1251-7. doi:10.1016/j.biombioe.2009.05.013.

58. Wang L, Toppinen A, Juslin H. The use of wood in green building: a study of expert perspectives from the UK. J Clean Prod. 2014;65: 350-60. doi:10.1016/j.jclepro.2013.08.023.

59. Husgafvel R, Watkins G, Linkosalmi L, Dahl O. Review of sustainability management initiatives within Finnish forest products industry companies - translating Eu level steering into proactive initiatives. Resour Conserv Recycl. 2013;76:1-11. doi:10.1016/j. resconrec.2013.04.006.

60. Korhonen K, Hujala T, Kurttila M. Diffusion of voluntary protection among family forest owners: decision process and success factors. Forest Policy Econ. 2013;26:82-90. doi:10.1016/j.forpol. 2012.08.010

61. Haltofová P, Adámek P. Corporate social responsibility in companies of the primary sector in Czech Republic, a preliminary study. Procedia Econ Financ. 2014;12:206-12. doi:10.1016/S22125671(14)00337-2.

62. Kourula A. Corporate engagement with NGOs in different institutional contexts - a case study of a forest products company. J World Bus. 2010;45:395-404. doi:10.1016/j.jwb.2009.08.010.

63. Aquilar FX, Cai Z. Conjoint effect of environmental labelling, disclosure of forest origin and price on consumer preferences for wood products in the US and UK. Ecol Econ. 2010;70(2):308-16. doi:10. 1016/j.ecolecon.2010.09.002.

64. Brouhle K, Khanna M. Determinants of participation versus consumption in the Nordic Swan eco-labeled market. Ecol Econ. 2012;73:142-51. doi:10.1016/j.ecolecon.2011.10.011.

65. Toivonen RM. Product quality and value from consumer perspective - an application to wooden products. J For Econ. 2012;18(2): 157-73. doi:10.1016/j.jfe.2011.12.004.
66. Tsourgiannis L, Kazana V, Karasavvoglou A, Nikolaidis M, Florou G, Polychronidou P. Exploring consumers' attitudes towards wood products that could be derived from transgenic plantations in Greece. Procedia Technol. 2013;8:554-60. doi:10.1016/j.protcy. 2013.11.078.

67. Osburg V-S, Appelhanz S, Toporowski W, Schumann T. An empirical investigation of wood product information valued by young consumers. J Clean Prod. 2015;110:170-9. doi:10.1016/j.jclepro. 2015.01.068.

68. Hansmann R, Koellner T, Scholtz R. Influence on consumers' socioecological and economic orientations on preferences for wood products with sustainability labels. Forest Policy Econ. 2006;8: 239-50. forpol.2004.06.005

69. Appelhanz S, Osburg V-S, Toporowski W, Schumann T. Traceability system for capturing, processing and providing consumer-relevant information about wood products: system solution and its economic feasibility. J Clean Prod. 2015;110:132-48. doi:10.1016/j.jclepro.2015.02.034.

70. González-Garcia S, García Lozano R, Moreira MT, Gabarrell X, Rieradevall IP, Feijoo G, et al. Eco-innovation of a wooden childhood furniture set: an example of environmental solutions in the wood sector. Sci Total Environ. 2012;426:318-26. doi:10.1016/j. scitotenv.2012.03.077.

71. Hemström K, Mahapatra K, Gustavsson L. Perceptions, attitudes and interest of Swedish architects towards the use of wood frames in multi-storey buildings. Resour Conserv Recycle. 2014;55(11): 1013-21. doi:10.1016/j.resconrec.2011.05.012.

72. Simula H, Lehtimäki T, Salo J. Managing greenness in technology marketing. J Syst Inf Technol. 2009;11(4):331-46.

73. Parsons AG, Soo S, Berth N. Sustainability - is perception as good as reality? In: Kahle LR, Gurel-Atay E, editors. Communicating sustainability for the green economy. Society for Consumer Psychology; 2014.

74. Schmeltz L. Consumer oriented CSR communication: focusing on ability or morality? Corp Commun Int J. 2012;17(1):29-49. doi:10. 1108/13563281211196344. 